\title{
Response to second line antiretroviral therapy in India
}

\author{
Anup Singh*, Jaya Chakravarty, Anoop Gupta, Shyam Sundar, Madhukar Rai, Avinash Singh, Amit Agarwal \\ From First International Science Symposium on HIV and Infectious Diseases (HIV SCIENCE 2012) \\ Chennai, India. 20-22 January 2012
}

\section{Background}

Second line antiretroviral therapy (ART) was rolled out in India in December 2008. However, there has been no study to assess the response to second line ART in India. This study aims to see the response to the NACO recommended second line therapy over 24 week period.

\section{Methods}

Study was conducted in ART centre, IMS, BHU. Patients who failed on first line ART (NACO criteria) were included in the study after consent. Virological, immunological and clinical response was assessed at 24 weeks. Independent $\mathrm{t}$-test /Mann-Whitney $\mathrm{U}$ test was used for making comparison among the independent groups. Chi-square test was used to test the association between categorical variables. Spearman correlation coefficient was used to measure the degree of association between two variables.

\section{Results}

Out of 78 patients, only 39 (50\%) had virological suppression (viral load $<47$ copies $/ \mathrm{ml}$ ) and $20(25.6 \%$ ) had partial response (viral load >47-1000), 10 (12.8\%) had viral load $>1000$ copies $/ \mathrm{ml}$ and $8(10.3 \%)$ patients died before 6 months and 1 patient was lost to follow up. Median increase of CD4 count was 133 cells / $\mathrm{ml}$ (IQR -46-498). Among patients who expired $90 \%$ had clinical failure at baseline, $50 \%$ and $18.75 \%$ were in stage IV and III respectively.

\section{Conclusion}

Currently recommended second line regimen appears to be inadequate as large proportion of patients failed to achieve the desired virological suppression. Our finding

* Correspondence: dranupbhu@gmail.com

Department of Medicine, Institute of Medical Sciences, Banaras Hindu University, Varanasi, UP, India implies a relook at the present second line regimen recommended by NACO.

Published: 4 May 2012

doi:10.1186/1471-2334-12-S1-P40

Cite this article as: Singh et al:: Response to second line antiretroviral therapy in India. BMC Infectious Diseases 2012 12(Suppl 1):P40.
Submit your next manuscript to BioMed Central and take full advantage of:

- Convenient online submission

- Thorough peer review

- No space constraints or color figure charges

- Immediate publication on acceptance

- Inclusion in PubMed, CAS, Scopus and Google Scholar

- Research which is freely available for redistribution

Submit your manuscript at www.biomedcentral.com/submit

\section{() Biomed Central}

C Biomed Central

(c) 2012 Singh et al; licensee BioMed Central Ltd. This is an Open Access article distributed under the terms of the Creative Commons Attribution License (http://creativecommons.org/licenses/by/2.0), which permits unrestricted use, distribution, and reproduction in any medium, provided the original work is properly cited. 